Гальянова Дарья

Казахстанско- Российский Медицинский Колледж

г. Алматы, Казахстан

E-mail: darya.galyanova@bk.ru

ORCID ID 0000-0003-2946-7790

\title{
АНТИСЕПТИКИ ДЛЯ РУК
}

Galyanova Darya

Kazakh-Russian Medical College Almaty city, the Republic of Kazakhstan

E-mail: darya.galyanova@bk.ru

ORCID ID 0000-0003-2946-7790

\section{ANTISEPTICS FOR HANDS}

Annotation: This article discusses the importance of hand hygiene in the daily lives of people. Describes the actions that motivate people to use antiseptics. The advantages of antiseptics using in everyday life in the absence of access to water and various means of hygiene are considered. Identified the distinctive features of various types of antiseptics. Specified positive and negative properties in the application.

Keywords: antiseptics, alcohol, hygiene, destruction of microorganisms, povidone-iodine, alternative to hand washing, "sticky" effect.

Аннотация: В данной статье рассматривается значение гигиены рук в повседневной жизни людей. Описывает действия побуждающчие людей $\kappa$ применению антисептиков. Рассматриваются преимущества антисептиков с использованием в быту при отсутствии доступа к воде и различным средствам гигиены. Вылвлены отличительные черты различных видов антисептиков. Указаны положительные и отрицательные свойства в применении.

Ключевые слова: антисептики, спирт, гигиена, уничтожение микроорганизмов, повидонйод ,альтернатива мытью рук, «липкий» эффект.

На коже человека содержится около восьмидесяти процентов микроорганизмов микробов и бактерий, способных приводить к опасным заболеваниям. Именно поэтому так важна своевременная гигиена рук, ради здоровья их принято поддерживать в чистоте и порядке. Но как быть, если нет возможности воспользоваться стандартной процедурой мытья? На помощь приходят антисептики. Одним из видов антисептика является гигиенический гель. Гигиенический гель отличается высоким уровнем эффективности, выраженной в 88\%, так как все патогенные бактерии чувствительны к антисептикам. Антисептики и дезинфицирующие средства очень важны в повседневной жизни людей. Они давно нашли себе применение в медицине, но для бытовой эксплуатации продукты стали выпускаться совершенно недавно. Современные производители средств личной гигиены разработали широкий спектр препаратов, которые имеют свою особенность и специфику применения. Например, для лиц, которые постоянно сталкиваются со счетом денег, есть особые антисептические препараты, направленые на уничтожение бактерий наиболее часто присутствующих на купюрах.

Антисептик для рук - Дезинфицирующее средство используется в повседневной жизни для, предотвращения передачи патогенных микроорганизмов, а так же для соблюдения правил гигиены рук там, где не доступны умывальники и мыло, является дополнением или альтернативой мытью рук с мылом и водой. Имеются различные формы такие как пена, гель, жидкий раствор, спрей, обработанные салфетки. 
Состав антисептических средств для рук определяется их типом. При этом антисептические средства одного типа могут включать в себя несколько активных компонентов, повышающих эффективность препарата для повседневного применения среди населения. Типы антисептиков для рук: на основе спиртов; на основе органических кислот; с поверхностно активными компонентами; кислородонасыщенные и т.д. В антисептике для рук активным ингредиентом может быть повидон-йод, изопропанол, этанол. Антисептики могут включать в себя загуститель такой как полиакриловая кислота пропиленгликоль, увлажнители, такие как глицерин, а также эфирные масла растений.

Спиртосодержащие антисептики для рук убивают огромное количество различных видов бактерий включая бактерии устойчивые к антибиотикам и микробактериям туберкулеза. Они характеризуются высокой вирусологической активностью против различных видов вирусов такие как вирусы гриппа, ВИЧ и ОРВИ, но являются самыми не эффективными против вируса бешенства. Также спиртосодержащие антисептики для рук уничтожают грибки. Для эффективной борьбы с микробами концентрация спирта в антисептиках для рук должна быть свыше 60\%. Спиртосодержащие антисептические средства для рук рекомендуется применять в бытовых условиях для населения, в местах большого скопления людей, в которых отсутствует доступ к мылу и умывальнику с водой.

Чтобы защитить кожу рук от чрезмерного высушивания, в состав большинства спиртовых антисептических средств входит увлажнитель- хлорид бензалкония. Использование хлорида бензалкония может вызывать аллергические реакции у некоторых людей.

Но несмотря на это аллергические реакции на хлорид бензалкония очень редки, увеличение антимикробной эффективности превышает намного подобные риски. Хлорид бензалкония накапливается на коже, как правило при очень частом использовании антисептика для рук в течение дня, поэтому большое скопление может привести к «липкости». Гелеобразные антисептики для рук оставляют «липкие» остатки из-за гелевой структуры. Гель не имеет особенности испаряться и остается на руках, пока не будет удален с помощью воды и мыла. Известны также кожные антисептики на основе Повидон-йода. Данное соединение хорошо растворимо в воде, спиртах, а так же глицерине и этиленгликоле. Впервые появился 1955 году и с тех пор стал универсальным широко используемым кожным антисептиком. Обладает более низкой токсичностью по сравнению с другими йод-содержащими препаратами. Йод в данном соединении очень слабо всасывается в кожу. Основным недостатком повидон-йода являются случаи покраснения кожи, зуда и раздражение тканей на месте применения.

Спиртосодержащий гель может гореть и воспламеняться пламенем тускло голубого цвета. Так как в состав геля входит легковоспламеняющийся спирт. Известно несколько редких случаев, когда спирт повлек за собой пожар в рабочей зоне. Имеются случаи, когда люди пили антисептические гели в тюрьмах и больницах для снятия похмелья, что привело к отмене их использования в некоторых заведениях.

Инструкция по использованию антисептиков. Антисептические средства применяется исключительно для наружной обработки рук и поверхностей. Запрещено обрабатывать веществом слизистые оболочки тела и раны. Следует избегать контакта с открытым пламенем. Не подлежат к использованию после окончания срока годности. Если антисептик попал на слизистую глаз, то их следует промыть чистой водой и закапать 1-2 капли 30 \% раствора сульфацила натрия. Если ребенку или взрослому средство случайно попало внутрь, то необходимо принять абсорбенты: активированный уголь (10- 
12 измельченных таблеток) или жженую магнезию (1-2 ст. л. на 1 стакан воды). Рвоту вызывать не нужно, при ухудшении самочувствия следует обратиться к врачу.

Рассмотрим несколько видов антисептиков:

Антисептический препарат Стериллиум (рис.1) - это средство на спиртовой основе, представляется в виде геля с дозатором. Состав содержится в удобной емкости объемом почти в пол литра и в небольших флаконах для ношения с собой. Данный антисептик применяется для очищения рук в рамках личной гигиены так же для обработки кожных повреждений с целью предотвращения заражения. Средство эффективно в борьбе с вирусами герпеса группы А, гриппа, гепатита, стафилококка, кишечной палочки и пр. Для применения следует нанести гель на ладони рук и хорошенько растереть их. Процесс защиты включается через 30 секунд после нанесения на кожу рук.

\section{Pис.1 Антисептик Sterillium (Стериллиум)}

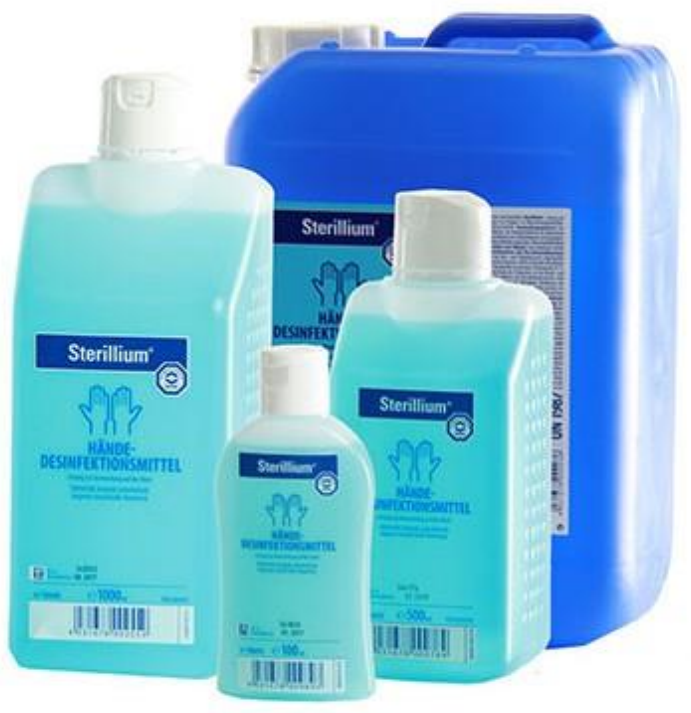

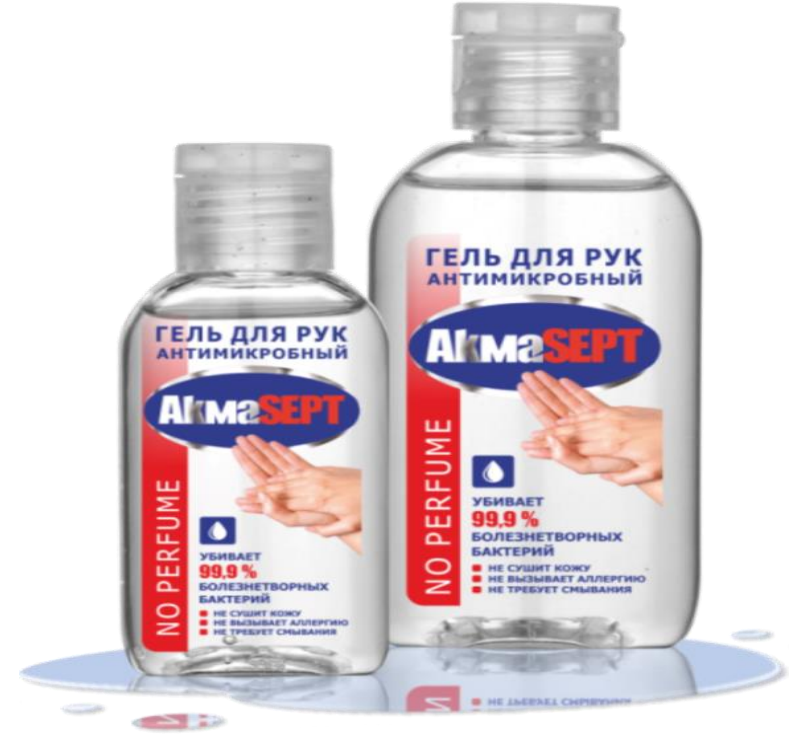

Рис.2 Антибактериальный гель для рук «AkmaSEPT

Гель для рук «AkmaSEPT» (рис. 2) Гель удобно использовать для дезинфекции рук перед употреблением пищи, если под рукой не оказалось проточной воды. Обеззараживающий гель убивает множество бактерий: кишечную палочку, золотистый стафилококк, диплоидный грибок. Удобен в использовании, быстро впитывается и не оставляет пленки на руках. По сравнению с другими антисептическими средствами гель AkmaSEPT не сушит и не стягивает кожу. Средство заботится о состоянии дермы, увлажняя и смягчая ее. По сравнению с обычными салатиками данный антисептический гель экономнее и практичнее. Средство удобно брать в дорогу.

Антисептический гель Sanitelle (рис.3) - это качественный продукт, являющийся эффективным антисептическим средством для обработки рук и предметов. Состав уничтожает за несколько секунд 99 процентов всех известных инфекций и бактерий, что делает его незаменимым для ухода за кожей рук. Средство содержит в своем составе экстракт алоэ и витамины группы Е. Обладает приятным запахом. Средство не вызывает аллергических реакций и может применяться для всех типов кожи.

Антибактериальный гель Dettol (Деттол) (рис.4)-является эффективным антисептиком на спиртовой основе. Имеет специфический спиртовой запах, который достаточно быстро выветривается. Антисептик за считанные секунды уничтожает 

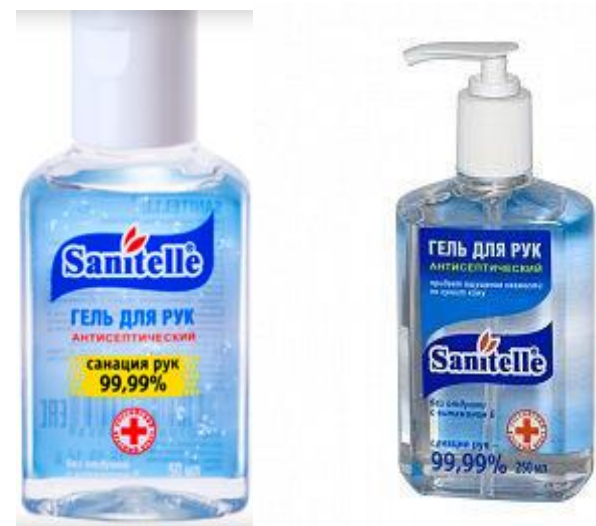

Pис. 3 Антисептический гель Sanitelle

бактерии и микроорганизмы, находящиеся на коже рук. После использования эффект вымытых рук длится в течение нескольких часов, что довольно удобно для бытового применения средства.

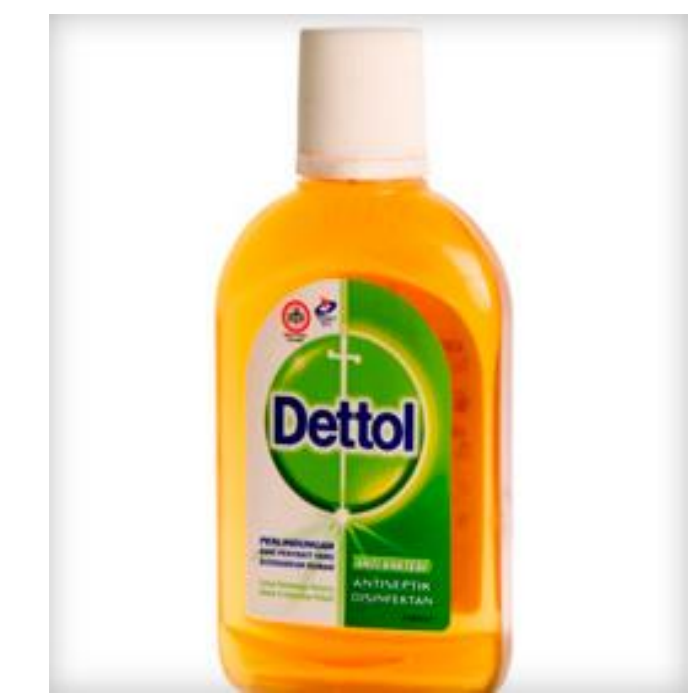

Рис.4 Антибактериальный гель Dettol (Деттол)

\section{ЛИТЕРАТУРА}

1. Антисептика // Энциклопедический словарь Брокгауза и Ефрона: в 86 т. (82 т. и 4 доп.). СПб., 1890-1907.

2. Дезинфекция. Антисептика, №1, 2018; Велт - Москва, 2018. 243 с. Винник Ю. С., Кочетова Л. В., Карлова Е. А., Теплякова О. В. Асептика и антисептик; Феникс, Издательские проекты - Москва, 2018. - 128 с.

3. Фроленко С.И. Асептика и антисептика. Справочник для медицинских сестер; Феникс Москва, 2005. - 192 с.

4. Ванюков Д.А. Три уровня обработки рук (5 октября 2014).

5. Рекомендации по мытью и антисептике рук / Под ред. академика РАЕН Л. П. Зуевой. - СПб: Санкт-Петербургский Учебно-методический Центр Инфекционного Контроля, 2008. - 38 с.

6. Сливинская С. Ф. Технология обработки рук медицинского персонала // Главная медицинская сестра. - 2009. - № 8. - С. 156-159. 